\title{
Administrative simplification strategy with reference to the Egyptian case
}

\author{
Reem Mostafa Gobba
}

\author{
Department of Public Administration, Faculty of Economics and Political Science, \\ Cairo University, Giza, Egypt
}

\begin{abstract}
Purpose - This paper aims to clarify the added value to governments when adopting an Administrative Simplification Strategy (ASS) to reduce administrative burdens, and its impact on both citizens and investors satisfaction. The paper highlights the difference between the traditional and strategic concepts of simplifying administrative procedures, Moreover, the paper discusses the most important steps and tools for the implementation of ASS. The paper, also, sheds light on the efforts of the Egyptian Government to simplify administrative procedures and adopt ASS.

Design/methodology/approach - This paper adopts the descriptive analytical approach to describe and analyses the basic features of the subject data from different resources includes journal articles, published papers and books, to conclude a theoretical framework of ASS. (concepts, Implementation steps, Tools, Objectives, operations and content). For the Egyptian case, the researchers uses historical perspective to analyze the efforts of the Egyptian government to simplify administrative procedures in the last decades and the content of the available ministerial decisions, presidential decrees, for example The last ministerial decisions concerning the one-stop supreme committee, were chosen as evidence of the government's interest in this matter and the analysis of the tasks entrusted to the committee to do, The decision of transfer the dependency of the ERRADA was also chosen and analyzed to indicate the extent of the government's interest in it and to what extent there is an enhancement of its role. The authors also analyzed some recent conferences and seminars and compared the administrative reform efforts with the theoretical framework of the ASS to clarify the dimensions related to ASS in Egypt.

Findings - On the theoretical level, the ASS is an umbrella term that includes various simplification projects at all the levels of governmental units. ASS leads to the improvement of governmental services provided to both citizens and investors. It is a defensive exploratory strategy that involves multiple goals and processes and requires political support, institutional framework and the comprehensive review of all related legislations, to ensure the successful implementation. Studying the Egyptian case, it is noted that the Egyptian government has not directly adopted an ASS. Yet, it has approved some stages within the framework of the adapted administrative reform plans.

Originality/value - This paper represents a framework for administrative simplification as an integrated strategy at the macro level. The strategy focuses on the overall view of the government, its integrated goals, innovation and the added value, by providing high-quality services and reducing the administrative burdens, as to improve services provided to society and ease of life, as well as to increase the level of living and citizens' satisfaction.
\end{abstract}

Keywords Egypt, Public administration, E-government, Administrative simplification strategy (ASS), One-stop shop

Paper type Research paper

(C) Reem Mostafa Gobba. Published in Journal of Humanities and Applied Social Sciences. Published by Emerald Publishing Limited. This article is published under the Creative Commons Attribution (CC BY 4.0) licence. Anyone may reproduce, distribute, translate and create derivative works of this article (for both commercial and non-commercial purposes), subject to full attribution to the original publication and authors. The full terms of this licence maybe seen at http://creativecommons.org/ licences/by/4.0/legalcode 


\section{JHASS 4,3}

\section{Introduction}

Governments strive to increase the quality of public services provided to citizens -such as education and health, and to the investors such as license, tax and customs. These services cannot be provided without adopting a set of procedures that reflect the detailed steps to be followed to obtain these services. The procedures are considered a means to implement the public policies, enhance transparency and accountability and contribute to improving the quality of life. However, the increase in the number of procedures creates a state of confusion and complexity.

Since the late 1990s, a number of key concepts such as governance, networks, partnerships, government integration, transparency, accountability and trust have been adapted and implemented. Yet, the coordination among different government units, which is intended to achieve a high degree of cooperation and integration, resulted in difficulty to achieve the overall objective of state policies. This leads the public policy makers and practitioners to adapt the strategic management approach and develop a set of strategies. One of these strategies is the Administrative Simplification Strategy (ASS) that enables the government to achieve the targeted level of coordination and integration between the different governmental units and entities, while ensuring the provision of quality public services Since the year 2000, the Organization for Economic Cooperation and Development (OECD) and its thirty member states have made a great effort to implement an ASS, which includes projects, programs and tests to measure and evaluate administrative burdens resulting from various government procedures. The majority of the countries in the organization committed themselves to it. Accordingly, the strategy has resulted in raising the efficiency of government services and the degree of public satisfaction. (OECD, 2003) In 2007, OECD started cooperating with countries of the Middle East and North Africa to simplify administrative procedures and transfer the experiences of its member states in implementing a strategy to simplify procedures. Some Arab countries, including Egypt, have started steps to simplify administrative procedures. Two seminars were held in Cairo. The first, entitled "Good Governance for Development Service," was organized in cooperation with the Ministry of Administrative Development in 2007. One of its most important axes was the simplification of administrative procedures. The second seminar was held in 2008, entitled "Simplification of Administrative Procedures Overcoming Obstacles to Implementation". It included storing and reviewing regulations, as well as electronic registration of laws and regulations on the e-government portal, to improve the business climate and efficiency in providing governmental services (OECD, 2009)

The ASS adopted by government units brings about a planned change consistent with public policies and establishes interconnecting programs that involve the whole government based on information and communication technology. As a result, it reduces administrative burdens, raises the level of efficiency in providing services and applies the principles of transparency and accountability.

In this study, the theoretical basis for the ASS and its steps and tools for implementation are covered. The simplification administrative initiatives of the Egyptian government are analyzed in light of the ASS framework.

This argument of this paper is presented through three main axes:
A. Adopting the concept of strategy in public administration.
B. ASS: Concept, Implementation steps and Tools.
C. The Egyptian case. 


\section{A - Adopting the concept of strategy in public administration}

Research in strategy theory and practice was known only as one of the business administrations fields. Meanwhile, the approach used by governmental organizations in

setting their plans was the logic of rationality, where the profit and loss concepts were unused. For these two reasons and others, the strategy received no attention by the public administration researches until the emergence of the NPM movement at the end of the eighties and the early nineties. Accordingly, the current conceptual framework and the strategy in public administration are addressed through the following two main points:

(1) Strategy in the public administration literature:

The term strategy at the level of public organizations did not crystallize seriously before the 1980s, through some scattered definitions. Vancil (1976) defines strategy as "the main source of cohesion for workers in government organizations." Rabin et al. (1990) defines strategy as the theoretical frameworks, techniques and plans used by managers to remove threats and take advantage of the improved opportunities, to achieve development and security in public organizations. Schwnk (1995) refers to strategy as "the way of thinking to make decisions and implement them to reach the general goals that the governmental organizations seek to achieve."

At the macro level of the government, Morgan and Sturdy (2000) define the strategy as a perspective that reflects the perception of political systems of the surrounding world and the theoretical and practical frameworks they use to interact with the environment. According to Butler (2003), the definition of strategy differs, as it is a political rather than an administrative document. It is considered as a contract between politicians, bureaucrats and technocrats who execute the strategy, by considering other stakeholders, such as citizens and non-profit organizations. The process of strategy in public administration becomes more complicated, because of the large amount of information and data and the multiplicity and the conflict of interests.

The word "strategy" is used in various ways by governments. Sometimes, it means the activities needed to implement political decisions, or the details of the programs needed to implement the policies approved by Parliament. Other times, it refers to a set of decisions related to asset selection, reliance on external or internal sources, human resources and financing.

Strategy implementation at the level of governmental organizations did not begin until the end of the eighties and the early nineties, when it was always considered that strategic management was only one of the areas of research and education in the field of business administration. This reflects back on legislative framework, government plans linked to rationality, wide geographical scope and the leadership focus on the outcomes (Gene, 2009).

The most important factors and justifications that have strengthened the government approach to strategies are the complexity of the problems and societal issues, the increasing awareness of the masses and the pressures of international and regional organizations on countries to adopt strategic directions in accordance with international treaties and agreements (Alkobis, 2010).

The strategy is a means for implementing public policies, It contributes to the development of public policies making and implementing methods. The strategy is a mixture of objectives to be achieved and the means that guide them, including policies and procedures. Therefore, the relationship is reciprocal and complementary between public policy makers and strategy developers (Butler, 2003).

According to Hoglund (2011), the implementation of strategies at the governmental level includes, formulating a future vision for the government and its organizations, linking 
JHASS 4,3

performance to medium and long-term goals in an integrated manner, linking strategies and budgeting and providing feedback to reduce the strategic gap between domestic and international practices.

(2) Levels of strategy in public administration:

There is a set of attributes that should be considered in case of adopting the strategy by entities of public administration, due to the absence of competitors and consideration for profitability. The success of the strategy does not lead to significant financial rewards for those in charge. Moreover, the consumers of the service do not pay the full cost directly, even if a portion is collected through taxes (Flynn and Bell, 2016).

The outputs resulting from the implementation of a strategy may be identical to the set political goals, or totally different. There may be some deviation from these goals, depending on the extent of separation or proximity between the political goals, and the administrative dimension upon application (Schwnk, 1995).

Stewart (2004) defines three levels of strategies in public administration:

(1) Policy strategy is the starting and reference point for any strategy adopted by governmental organizations. It is defined as what the government wants to change and places on its agenda. The policy strategy represents an ongoing relationship between the political leadership and its administrative arm to publish, implement and develop policies set by governments.

(2) Organizational strategy is the strategy adopted by the governmental organization to meet the needs and expectations of its various stakeholders. In order to be able to continue in its environment, formulating this strategy starts from the political strategy.

(3) Managerial strategy is the frame work that governs and reflect the set of technical and operational decisions related to the budget and resource allocation to achieve the organization goals.

Building a strong alliance internally - with employees, and externally - with different stakeholders - is considered key to the success of any strategy. Each type of the above strategies has an official, who focuses on the added value the strategy provides. The choice of strategy and tools for its execution in public organizations are affected by many factors. They include the environmental factor, which is the external and internal environment and the transactional factor, which marks the compliance of the clients with the steps and procedures set by the organization to implement its strategy and the scope of the organization's impact (Smith and McBain, 2010) (Pucek and Spacek, 2014).

\section{B - administrative simplification strategy: concept, implementation steps and tool}

The ASS is one of the strategies that is adopted to development and improvement the method of providing services to the public. Its adoption affects the various activities within the public organizations, and leads to a distinctive situation (David and David, 2017).

\section{Concept of administrative simplification strategy (ASS)}

Every public organization and the entire government level have to adapt an ASS to simplify work procedures, facilitate access to all parties -citizens and businessmen and to improve the performance of those organizations providing public service (Torres and Piana, 2005). 
Dragos (2016) defines procedure as a series of operations issued or performed by an administrative body The administrative procedures protecting the rights of different parties, collecting information, Working as a means of fairness in the event of litigation. (Hampton, 2005)

The cost of the procedure is the "political cost," which is the inherent cost in achieving the goals of the political action. There are "administrative costs," which costs incurred in collecting information and completing forms, in addition to the expected time to obtain business approvals.to reduce the overall cost of a procedure, it should be modified and published. The simplification methodology should evaluate the plans, programs, policy and strategy based on an assessment of the impact of procedures in the public sector (Gene,2009).

The Organization of Economic Cooperation and Development (OECD, 2003) has defined procedures simplification as:

- Reducing unnecessary papers, excessive administrative steps and duplication and increasing the coordination between the institutions involved in a particular activity.

- Reviewing and simplifying the papers and forms imposed on citizens.

- Reducing excessive regulations that impede work and decision-making.

The previous definition focus on Administrative Burden Reduction (ABR), which includes two main aspects. The first relates to excessive organization that focuses on the internal divisions and its internal and external relationships starting from defining roles and ending with models. The second aspect relates to cost in terms of time and effort, seeking to simplify procedures and reduce time and effort through using a strategy that targets the entire government based on coordination and consultation at all levels. (European Commission report, 2014).

Governments face a great challenge to strike a balance between the importance of the administrative procedure as a source of information and as a tool for implementing public policies. Consequently, they need a strategy to achieve this balance and a future vision for public organizations that help them face the obstacles in their work environment. This requires an integrated strategic plan that develops and improves all elements associated with the procedure, at the level of adopting the concepts of comprehensive quality, or modernity and change.

Napicks (2014) defines ASS as the planned change in the structures, which includes a change in the intensity, size and complexity of programs and its implementation tools, organization and operations, as well as individuals involved in implementation process. Based on this definition, the following points can be highlighted:

- Changing the structures to be more flexible and prevent duplication.

- The change aims at reducing the size and steps of implementing government programs and simplifying the complexity of the associated organizational design.

- Changing methods and means of communication with citizens

- Developing and training personnel involved in change implementation.

The OECD(2009) defines ASS as a set of interlocking programs taken from a long-term perspective and includes the entire government, aiming at improving the efficiency of transactions with citizens and businessmen without compromising the benefits of the system. In 2011, OECD has redefined ASS as a policy that leads to improving the efficiency 
JHASS

4,3

of public administration in providing services by reducing administrative burdens (ABR) and reducing excess or rigid requirements that prevent business facilitation or decisionmaking.

\section{Requirements for implementing administrative simplification strategy}

A set of requirements must be met when applying ASS to support the efforts of the various parties responsible for developing procedures and the governmental organizations responsible for providing services, to effectively implement the strategy and simplify procedures. According to the European Commission report (2014), OECD(2009), OECD (2011), these requirements can be presented as follows:

- Coordination between front and back offices:

Governmental organizations need to achieve streamlining between the front offices and back offices, this requires efficient administrative procedures that reduce the needed information, permits and licenses, To achieve parallel internal operations with the front office, coordination is required to reduce the associated procedures, in line with the political and administrative goals of public organization, (European Commission Report, 2014), (Aboudia, 2014) .

Internal operations refer to everything that helps the institution perform the assigned functions. They determine the necessary inputs to reach the expected outputs of their existence, such as providing services, to achieve their intended political and practical goal. The internal process is complicated when it passes by a number of organizations or multiple functions within the same organization. Therefore, ASS seeks mainly to answer two basic questions: how do public organizations perform their operations efficiently and effectively? How can all operations be grouped to facilitate the processes, by which users obtain services and without burdening their lives? (OECD, 2003).

- Adopt a comprehensive program that aligns with policy priorities:

The desire of countries to improve their economies and develop the level of provided services, while enhancing citizen compliance with some of their policies, as well as improving the level of citizen welfare are related to the adoption of ASS.

According to OECD (2003), OECD(2009), OECD(2011), Daddi (2014), Mascio et al. (2015), the application of ASS must contain a comprehensive program that is consistent with public policy priorities and based on the following axes:

- Collecting data from the beneficiaries and efficiently managing and updating them in a systematic way to ensure continuity and development, as ASS aims at sustaining administrative reform.

- Determining a quantitative goal for simplification and relying on quantitative methods to measure administrative burdens (Kafka test - Standard Cost Model $\mathrm{SCM})$.

- Administrative simplification should be an essential part of the philosophy or culture of governmental institutions.

- Creating units responsible for simplification within each institution and qualification of a work team for follow-up.

- The existence of strong political support to maintain the continuity of the driving forces, to complete the implementation stages and a legal framework that supports the strategy. 
- focusing on technical methods (information and communication technology), especially E- government.

The Egyptian

case

- Determining the priorities of administrative simplification -the most troublesomeaccording to cost and benefit.

- Determining the responsibility of each institution and clarity of its purpose for all parties, while allocating the appropriate authority to assume its full responsibility, for evaluation and accountability by the government.

- Focusing on the customer, through the participation of the beneficiaries of governmental services, whether units or civil servants, in setting the procedures, to which they must adhere, to obtain and provide various services.

- Promoting innovation and reform so that the government does not bear the financial burdens.

- Training the administrators of administrative simplification on creative methods of thinking through the various workshops. It can be the beginning of low-risk activities.

- Enhancing the presence of supporters of ASS inside and outside, to promote programs related to the strategy.

Success in the actual application of ASS is related to the method and tools for its implementation, as the application process contains many actors and specifies the goals and roles of the implementers.

According to the foregoing, ASS can be classified as an exploratory and defensive strategy, as it seeks to develop the existing service. It is, also, innovative in providing greater services and more customer coverage, as it focuses on procedures associated with providing services. It is marked by creativity to maintain its cost and improve the efficiency of its operations (Andrews et al., 2014). Therefore, information and communication technology is the basis on which most of the tools for implementing ASS are built. The following figure shows the objectives, operations and content of the ASS (Figure 1).

The difference between the traditional concept of simplifying procedures and introducing them as a strategy are shown in Table 1.

\section{Administrative simplification strategy implementation tools}

The studies of Costopoulou and Ntaliani (2010), Carrizales (2008), Goldkuhl et al. (2015) confirm that information and communication technology is the safe approach to ASS implementation. Different applications of information and communication technology, such as e-government, and one-stop shop, are used as the most important tools for implementing ASS, in addition, some administrative rules are used to achieve justice in accessing services and transparency in accessing information and promoting trust in government. The following section sheds light on e-government and one-stop shop.

\section{E-government}

The essence of e-government lies in changing the way citizens and organizations interact with the government. It is a concept that recognizes the need for governments to organize themselves around the actions and needs of citizens, through the reliance on information and communication technology. This is not limited to the mechanization of some service delivery operations, rather includes new business models based on re-engineering operations and 


\section{JHASS \\ 4,3}

186

Figure 1

Objectives, operations and content of the ASS

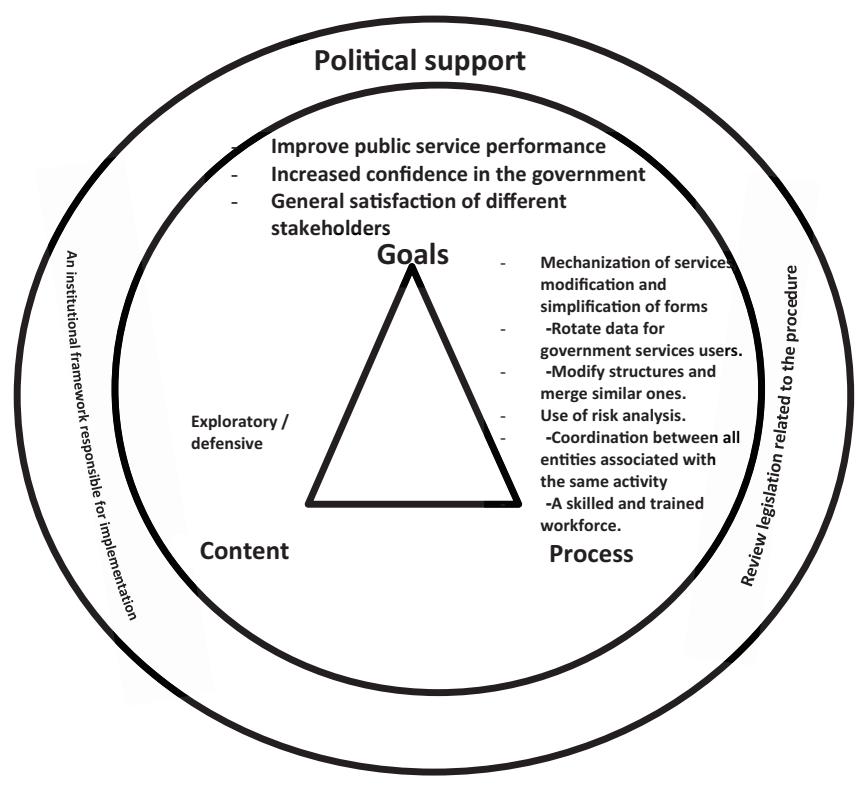

Source: The authors

information technology approach in the sense of making a fundamental change, not gradual improvements in existing structures (Arendsen and Engers, 2013).

There are various definitions of e-government. The World Bank (2011) has defined it as "the process of using governmental institutions for information technology (information networks - the Internet - mobile phone communication) which has the ability to change and develop relationships with citizens, businessmen and various related organizations, to serve many objectives:

- Providing better service to citizens.

- Improving interaction with businessmen and the industry community.

- Enabling citizen access to information.

- Supporting transparency and efficient management of governmental institutions.

- Reducing corruption, maximizing returns and reducing costs.

- Increasing the citizens' conviction in the role of governmental institutions in their lives, in a manner that enhances trust in governments.

The e-government framework links uses and applications to reform objectives and development outcomes and offers several merits. It focuses on the broad objectives and common challenges of public sector reform and identifies those applications that can potentially support multiple public reform objective. This includes, for example, using e-government in procurement, increasing competitiveness, providing transparent pricing, reducing corruption and improving the business environment (Costopoulou and Ntaliani, 2010). This is what ASS seeks to achieve through the various applications of e-governments. 
Simplification of procedures in the traditional sense

It does not mainly focus on information and communication technology to provide the service

The procedures within each organization are simplified individually without an integrated view with the other organizations linked to their activities

It does not treat the citizen as a customer whose needs must be addressed

The change is not done radically, rather by modifying the existing procedures and models, and reducing steps

It does not adopt the idea of excellence, or provide added value at the organizational or governmental levels
Simplification of procedures as a strategy

It mainly depends on information and communication technology (e-government) and all relevant applications to provide public services quickly and easily

It coordinates and offers support at all levels of government between similar activities, to achieve excellence in providing services and associated operations

It adopts the concept of the new public administration related to its overall view of the government, the integrated goals, coordination with all parties of the government, teamwork, and clearly stated procedures

It is innovative, and seeks to radically change the processes, then the procedures associated with them, with a holistic view of all organizations

Focuses on the priority of added value by providing high-quality services while reducing administrative burdens on beneficiaries by:

- It supports all activities and functions within all organizations individually, and simplifies procedures holistically.

- It reduces the operating cost by developing its methods based on information and communication technology.

It focuses on the procedure without a holistic view of business methods and service delivery tools

It relies mainly on process flow charts to record the procedural process as basic tools for simplification
It develops and improves all elements to the procedure, and links them to the concepts of total quality

It seeks to change the culture of the bureaucracy and the perception of their (inaccurate, please revise) role in providing public service
The Egyptian case

187

Source: The authors

Table 1. the Difference between the traditional and strategic concepts of simplification of procedures

The strategic goal of the e-government, which all countries of the world participate in, is to support and simplify access to governmental services for all concerned partiesgovernments, citizens and business establishment. E-government can, also, improve efficiency and reduce costs to government by improving supply chain management for goods and services, enabling more efficient markets, reducing travel and training costs, reducing fraud and duplication, automating routine transactions, consolidating field offices and improving program coordination and management (Carrizales, 2008).

From the foregoing, it is clear that the effective application of e-government requires radical re-engineering of various processes, so that they are transparent. This requires competencies and skills in human resources to deal with such technology, in addition to huge material resources and political leadership that support this transformation. Without the sovereign decision, the e-government remains an unworkable idea.

The reduction of the administrative burden is a major political issue. The proper use of ICT can help achieve this political aim. Consequently, e-government is seen as a means to help realize political goals instead of being a goal in itself (Goldsmith, 2004; West, 2009). 
JHASS

4,3

\section{8}

Zakee (2007) has pointed that the following steps are required to implement e-government as a tool to simplify procedures:

- Publishing information of interest to individuals and businesses about rules, procedures, documents and forms

- Interacting by expanding civil participation in government decision-making to build trust in the government

- Dealing by providing government services on spot, on line services, every time and place

The implementation of the e-government is related to ASS, which in turn is linked to the strategy of the government, its philosophy and vision with all parts of society. The internal infrastructure of the government is created based on such relations, including its organizational structure and the sequence of operations and coordination between external and internal changes, according to the management systems of governmental organizations at the global level (Wange, 2004).

\section{One-Stop shop (OSS)}

One-Stop Shop represents a group of jobs and departments under one roof. It is one stop through which multiple services are provided, as the customer can obtain the needed information and conduct all transactions with all responsible parties related to the needed service in the same place and time. The one-stop shop may target remote users by relying on information and communication technology, creating websites via the Internet and making applications for services on mobile smartphone devices. As a result, customers can obtain the needed services. This tool offers many benefits to various state facilities as it guarantees the payment of taxes, water bill, or electricity consumption bill, especially in border and rural areas (Minas, 2014).

There is no unified form for the design of a one-stop shop, since it is designed according to the required function. It is usually a kind of cooperation and coordination between different organizations. It does not require the integration of various entities. It is divided into three models or categories: (Askem et al., 2011):

\section{(1) Reception:}

This model plays an effective role in providing services, by providing the necessary information to the customer about the different authorities that must be contacted to obtain the needed service. This form of one-stop shop is considered one of the most limited forms of providing services.

(2) Surgery:

This model, like the doctor, is considered capable of diagnosis and analysis and has the authority to treat entanglements between different entities. It may refer the problem to higher specialists, in case of more complex problems. The therapist model is one of the most common and applied models.

(3) Multi-clinic:

This model is a full service, capable of managing the case from start to finish, from initial consultations to completion, with specialized assistance provided all the time.

Among the most important reasons for the successful application of OSS model is the accuracy of planning, good management of the window and its linkage to the steps of 
administrative simplification and process maps within public organizations. The establishment of OSS is subject to some legal obstacles, since the legislation of some countries assigns responsibility to specific levels of government, which hinders the goal of

its existence. Therefore, the application may need some time to develop and adopt solutions in the legislative program of the government. In order to activate OSS, its activities must be promoted within the targeted groups, to reduce resistance when it is applied, and fear for power, and its transfer to others. Moreover, internal negotiations are extremely important to ensure the success of the application (Minas, 2014).

When applying OSS, the quality of the workers is determined according to the form of application. Thus, OSS is related to the process of administrative simplification, as it is a professional interface with the citizen or business organizations. It is simply a guide to transfer the service through the maze of management bureaucracy. This is its vital role. Yet, the real and economic benefits come from the cohesion of unrelated operations with one point (Bekkers and Zouridis, 1999).

According to what is mentioned about ASS, and the difference between the traditional and strategic concepts of simplifying procedures (Table 1), it is clear that ASS is an umbrella term that includes many simplification projects at all levels of governmental units. The implementation of ASS leads to improving governmental services provided to both citizens and investors.

\section{Egyptian case.}

The administrative entities are responsible for putting the general policies into practice. It is difficult to distinguish where the bureaucratic process ends and the political process starts. In an effort by the Egyptian state to improve the provision of public services, efforts have been made to simplify administrative procedures when preparing administrative reform plans. These efforts are presented as follow:

(1) Simplifying administrative procedures in administrative reform plans in Egypt:

Egypt is one of the oldest countries in the world that witnessed a bureaucratic entity. The phenomenon of bureaucracy has misunderstood the concept of the public good, including what has been reflected on the role of public administration in the Egyptian state when providing public services for citizen and investor (Affendi, 2003).The axis of simplifying administrative procedures and reviewing legislation was a greater common denominator in all administrative reform plans introduced in Egypt, (Khashaba, 1984; El-Dakan, 2004; El-Sayed, 2007; CAOA,1967), as follows:

- The fifties stage, in which the administrative reform program was characterized by consultations of a number of foreign experts, the establishment of a ministerial committee for public services, the organization of government administration and the simplification of procedures in 1957.

- The stage of the sixties is characterized by the expansion of the role of the administrative entities, the establishment of the General Administration of Organization and Arrangement of Jobs in the Staff Bureau in 1960, with the aim of conducting research on improving work methods and simplifying procedure, followed by establishing the Central Agency for Organization and Administration (CAOA) in 1964 to provide assistance and give advisees on organizing processes, simplifying procedures and improving work methods.

- From the eighties until the late nineties, CAOA and the Ministry of Administrative Development formulated plans that aimed at developing 
JHASS

4,3

190

governmental services closely related to citizens, simplifying work procedures for some basic services that relate to the public and specifying the timing of the performance of these services to provide them in the appropriate manner and timing. About 168 studies were prepared to simplify the procedures based on flow charts for developing work systems, which amounted to 230 studies in 2000 (Ministry of Administrative Development Report, 2001).

- The first decade of the third millennium witnessed the deepening of the administrative reform based on market policies. Strategic goals were established, on top of which an efficient structure of the administrative entities aimed at raising the efficiency of public services provided, by re-engineering work cycles of governmental service in a way that leads to their focus in one step that can be reached through multiple service delivery channels.

- In the second decade of the third millennium, and after a period of political turmoil in the country from 2011 until the declaration of the constitution in 2014, the state began to formulate a comprehensive vision to reform various areas. A strategy for sustainable development was formulated, aiming at conveying a vision for Egypt in 2030 (Egypt's Vision 2030). A set of steps has been put in place to simplify complex structures by setting a methodology for restructuring the state's administrative entities, defining the strategic role of ministries, focusing them to their primary mission, integrating similar and convergent activities (and departments), reducing consultative units of the competent authority and asserting continuity and sustainability of policies and programs by creating the position of permanent agent in all state agencies (Civil Service Law, 81 of 2016).

(2) Practical steps and tools adopted by the egyptian government to simplify administrative procedures:

With the stable conditions in Egypt in 2014, the Ministry of Planning, Follow-up and Administrative Reform (2014) began to investigate the administrative problems. The complexity of the state's organizational structures was the top of these problems, due to the following reasons (Ministry of Planning, report, 2014, 2015):

- The number of ministries, government departments and administrative units reached 295, and about 2,449 administrative entities.

- The absence of criteria for the establishment and amendment of state's organizational units.

- Conflicting powers and responsibilities and the absence of specific goals.

These reasons resulted in:

- distortion, complexity and inconsistency in providing various services to citizens or investors,

- organizational instability and increase in the financial burdens on the state and administrative burdens on citizens and investors,

- difficulty in coordination and evaluation; and

- The emergence of various organizational conflicts.

The researchers used the above-mentioned ASS framework to answer the question on the extent of which the Egyptian government adopted a strategy to simplify administrative procedures, as analyzed in Table 2 . 


\section{Item/Dimension}

The extent to which the

ASS concept is adopted

Measuring administrative burdens

Practically adopted steps to simplify procedures and their compliance with ASS implementation steps
The Egyptian Case

Continuous efforts to simplify administrative procedures within the administrative reform plans to improve the country's position with various international indicators, and to attract more investments, in response to requirements of international organizations

No quantitative methods (SCM and KAFKA TEST) have been adopted to measure administrative burdens imposed by existing or new regulations and procedures

Establishing ERRADA (Egyptian Regulatory Reform and Development Activity) as a politically supported unit with branches, within government entities in 2007 , to simplify all procedures and requirements related to economic activity, and stimulate investment. ERRADA moved between different ministries until the final decision to affiliate it with the Egyptian cabinet

Setting out the terms of reference and responsibilities, and the clear distribution of tasks of each unit within the government, in addition to the development and standardization of performance indicators.

Strong political support to all government leaders to simplify procedures, and the maintenance of the driving forces for simplification. One manifestation of this support is the transfer of the responsibility of ERRADA directly to the Cabinet

The systematic update of information collected from the beneficiaries, and used in more than one service, where the 48 government agencies were connected and integrated on the digital converter G2G, in June 2018. Focusing on activities relevant to investors in the fields of tourism and agriculture when setting priorities for simplification in administrative reform plans

Customer Focus (Government/ Citizen/ Businessmen) approach in the implementation. For example:

Promoting innovation and reform to reach advanced alternatives, and provide different services by offering Egypt Award for Government Excellence, and the Individual Innovation and Creativity Award

Coordinating between the front and back offices by increasing the places for providing services, multiplying reception channels, developing technological centers in governorates, and creating a group of departments in all units of the state's administrative apparatus in line with modernization, in addition to the development and digital transformation in the country

Using information and communication technology (ICT) to improve the provision of some public services, considering the type of customer to whom the service is directed (an investor, citizen, or government employee), such as automating tax payment while updating and developing legislation related to tax administration, designing an integrated set of technological solutions, such as the electronic smart card to spend Supply Commodities- which is a multi-application technology, call centers, and Government Finance Management Information System (GFMIS) operating as a secure electronic integrated system that links all public government agencies, and contains all the functions of public financial management. There are, also, various efforts in several ministries to provide their services depending on ICT, including the Ministry of Interior, the Ministry of Health and Population, and the Ministry of Electricity and Energy)

Reliable tools to simplify administrative procedures
E-government

The Egyptian e-government program was launched in partnership with the Ministry of Communications and Information Technology, and the Ministry of
The Egyptian case

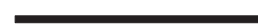




\section{JHASS 4,3}

Item/Dimension The Egyptian Case

Administrative Development in 2001. The program was divided into two phases; the first from 2001 to 2007, and the second phase from 2007 to 2012. The Egyptian government launched the application of "my government" in 2015 in cooperation with the Ministry of The Ministry of Planning, Follow-up and Administrative Reform, and the Ministry of Communications and Information Technology in an effort to provide services around the clock ( 24 hours a day, 7 days of the week). The application allows obtaining governmental documents such as driving licenses, birth certificates, and educational certificates, and delivering them to the citizen's home, as well as providing several means of electronic payment through Fawry and credit card outlets. The Egyptian government portal provides around 200 interactive governmental services. Despite these efforts, the e-government reports have displayed a decline in Egypt's rank from28 to 114 since 2008 to 2018.

One-stop shop

Establishing an institutional framework for establishing the Supreme Committee for One-Stop shop.

Forming an executive committee for the Egyptian Trade Network to reduce the number of documents, as well as the cost and time for import and export operations, and customs release from $32.7 \%$ in 2014 to $47 \%$ in 2030 .

Establishing a number of 19 logistic centers, and developer centers to facilitate customs release operations on Egypt's imports, to reduce the release time to reach international levels.

Establishing technological centers in cities and neighborhoods, providing around 110 services, 11 services for neighborhoods and cities, and 15 services for the governorates of all offices

Source: prepared by the author through the following: The Ministry of Planning, Follow-up and Administrative Reform, report, 2014, 2015 .Abdel-Rahman (2019), Labib, Ghada, (2019), Prime Minister Decree No. 998 for the year 2019, No. (20) for the year 2019, No. 4248,2918 for the year 1998, No.173 for the year 2011, CAOA decree No. 87 for the year 2019, Presidential Decree No. 89 for the year $2017 \mathrm{http}: / / \mathrm{mpmar}$. gov.eg,www.errada.gov.eg, www.incometax.gov.eg www.tamwin.com.eg, www.gfmis.mof.gov.eg, e-government reports from 2008 to 2018 www.egypt.gov.eg/Arabic/Home.aspx, EgyptVision2030, the axis

Table 2 .

According to the discussion of the Egyptian case (Table 2), it is clear that Egypt still suffers from a gap between stated laws and regulations and actual implementation. On the level of MENA countries, Egypt has the largest gap between the quality of rules and regulations and their enforcement in practice (OECD, 2018). In addition, it is clear that the Egyptian government did not adopt an integrated specific ASS, but adapted some stages of ASS, within the framework of administrative reform plans.

\section{Results}

Upon the investigation and analysis of the research subject, using the descriptive analytical design and historical perspective, the main results are summarized as follow:

(1) There is a difference between the traditional and strategic concepts of simplification of procedures, as simplifying procedures in its narrow sense maintains the system with its clarity and improves its efficiency. However, ASS in its broader sense reduces administrative burdens and corruption and increases social welfare and ease of life for all beneficiaries, while achieving the political and strategic goals of the government. 
(2) It is clear that ASS is an umbrella term that includes many simplification projects at all levels of governmental units. The implementation of ASS leads to improving governmental services provided to both citizens and investors.

(3) ASS is an exploratory-defense strategy that seeks to develop existing service and innovate the provision of better services. It, also, aims to increase the general satisfaction of different stakeholders and trust in the government.

(4) The most important tools for implementing ASS strategy are the E-government and one-stop shop.

(5) According to the discussion of the Egyptian case, the results are summarized as follows:

- It is clear that Egypt still suffers from a gap between stated laws and regulations and actual implementation.

- The absence of an integrated strategy for the simplification of administrative procedures resulted in a set of limited results achieved by the unit of ERRADA.

\section{Discussion}

The main objective of simplification activities is to improve the quality of public services and achieve a high level of stakeholder satisfaction.

Considering the contemporary changes, such as the tremendous technological development, the information revolution, and the increase in citizen expectations for public services, the government must transform into an effective one (inaccurate use. Revise), according to several criteria, including the extent to which its administrative activities operate in ideal conditions, the extent of participation of the stakeholders when developing different procedures and policies, and the adoption of different simplification tactics that improve the business environment and citizen satisfaction.

ASS supports the continuous change through enhancing the elements of government transparency and accountability, by creating an effective regulatory environment, which results in increasing the competitiveness of national economy. Moreover, ASS has a wide range of strategic options related to innovating operations, and new methods to provide services, or cover new customers, through participation and cooperation with all stakeholders.

The successful implementation of ASS requires political support, review of the legislative framework for procedures, and the existence of an institutional framework responsible for strategy implementation.

During the last two decades in Egypt, the government made sound efforts to enhance the administrative reform. However, the results were not sufficient to solve all the issues facing citizens and investors (OECD, 2018). This is evidenced by the following:

- The unit of ERRADA is an initiative to simplify procedures. During the last eleven years of work, the dependency of the unit has been transferred between more than one ministry since its establishment, before finally becoming one of the units under the supervision of the Cabinet directly. The lack of clarity of its vision, role and ownership lead to the following.

- The decline of the Egyptian e-government ranks from 28 to 114, during the last 10 years, from 2008 to 2018. This is an indicator of the limited use of information and communication technology, leading to the increase in operational cost, with the decrease in quality of public services. 
JHASS

4,3

- The absence of focus on critical objects when setting priorities for administrative simplification.

- The awareness and culture of bureaucracy when providing public services remains unchanged.

This present analysis of the available documents pertaining to the current situation in Egypt mentioned in Table 2 shows that there are no clear efforts to coordinate and integrate the administrative simplification programs at all levels of government, between similar activities, to supports each other and achieve excellence in providing services and associated operations.

\section{Conclusion}

According to what was discussed and analyzed in the paper, the implementation of ASS contributes to enhancing the competitiveness of countries, the business environment, societal welfare and ease of life for all stakeholders, in addition to reducing corruption. The tools used in simplification differ according to the different organizational levels and countries' policies and context.

Analyzing the Egyptian reality in the field of adopting a strategy to simplify administrative procedures indicates the absence of a comprehensive vision, despite the clear efforts made to simplify administrative procedures, within the plans of administrative reform.

To enhance the process of administrative simplification in Egypt, the government and policy makers have to pay more attention to the following objects:

- Legislative support and technological infrastructure to ensure effective and integrated information systems.

- Strong political support to ensure the success of implementing a total solution, not an isolated effort within the administrative reform plans.

- Focusing on the most disturbing points for citizens and investors, to boost confidence in the simplification efforts and to support all the related steps.

- Assignment of one clear entity to be responsible for directing and following up the ASS implementation, to ensure responsibility and accountability for the targeted results.

- Technological infrastructure in government units to facilitate the process of coordination and exchange of information.

- Policy making should join the public sector knowledge and experience to empower the knowledge workers.

- Various e-government applications can help improve ASS management and implementation and enhance the policy making process, to achieve the targeted results.

\section{Future studies}

What was presented in this research paper shows the need for future studies and researches, focusing on the following dimensions:

- The relationship between ASS and some approaches to administrative reform.

- Analyzing the experiences of some Arab and foreign countries in the application of ASS. 


\section{References}

Abdel-Rahman, S. (2019), "Real and hopeful administrative reform", Symposium at the Conrad Al Salam Hotel, Cairo, Ministry of Planning.

Aboudia, A.A. (2014), "Work and simplification of procedures", Second Arab Forum, Simplification of Procedures in Financial and Administrative Transactions, ARADO, Turkey.

Affendi, A.H. (2003), Management Democracy is a Path of Modernization and Development, Al-Ahram newspaper.

Alkobis, A.K. (2010), Approach to Strategies Research, ARADO publishes, Cairo.

Andrews, R., Boyne, G., Law, J. and Walker, R. (2014), Strategic Management and Public Services Performance, Macmillan Palgrave.

Arendsen, R. and Engers, T. M. V. (2013), "Reduction of the administrative burden: an e-Government perspective", Leibniz Center for Law, University of Amsterdam, The Netherlands, pp. 1-7, available at: www.lri.jur.uva.nl

Askem, J., et al. (2011), "One-stop shop for social welfare: the adaptation of an organizational form in three countries", Public Administration, Vol. 89 No. 4, pp. 1451-1468.

Bekkers, V.J.J.M. and Zouridis, S. (1999), "Electronic service delivery in public administration: some trends and issues", International Review of Administrative Sciences, Vol. 65 No. 2, pp. 183-195.

Butler, M.J.R. (2003), "Managing from the inside out drawing on receptivity to explain variation in strategy implementation", British Journal of Management, Vol. 14 No. s1, pp. 47-60.

CAOA (1967), Document No. (41), 1967, in the Central Agency for Organization and Administration, Previous Efforts in the Field of Administrative Reform, Central Agency for Organization and Administration, Cairo.

Carrizales, T. (2008), "Function of E-government: a study of municipal practices", State and Local Government Review, Vol. 40 No. 1, pp. 12-26.

Costopoulou, C. and Ntaliani, M. (2010), Measuring Administrative Burdens of e-Government Services for Rural SMEs, Agricultural University of Athens, Department of Science, Informatics Laboratory, Greece, pp. 435-442.

Daddi, T., et al. (2014), "Removing and simplifying administrative costs", Environmental Engineering and Management Journal, Vol. 13 No. 3, pp. 689-698.

David, F.R. and David, F.R. (2017), Strategic Management a Competitive Advantage Approach, 16 ed., published by Pearson Education.

Dragos, D. (2016), "Global encyclopedia of public administration", Public Policy, and Governance, Center for Good Governance Studies, Babes, Bolyai University, Cluj Napoca, Romania.

El-Dakan, A.E.-S. (2004), Evaluation of National Plans for Administrative Reform in Egypt from 19872002, Cairo Univ, Center for Public Administration Studies and Consultations.

El-Sayed, M.K. (2007), "Editor”, Institutional Reform and Development in Egypt, Development Partners for Research, Consultation and Training.

European Commission report (2014), Quality Of Public Administration, Theme4: improving service delivery.

Flynn, N. and Bell, J. (2016), Public Policy and Strategy, Centre for Financial and Management Studies, SOAS, University of London, pp. 24-37.

Gene, R.M. (2009), "Can management strategy minimize the impact of red tape impact on organization performance", Administration and Society, Vol. 41 No. 4, pp. 423-448.

Goldkuhl, G., et al. (2015), Visionary Design Research Renewing e-Government Support for Business Set Up, Department of Management and Engineering, Linköping University, Linkoping, Sweden, pp. $55-70$.

Goldsmith, S. (2004), Governing by Network, brooking Institution press, Washington, DC. 
JHASS

4,3

Hoglund, L., et al. (2011), "Strategic management in the public sector: how tools enable and constrain strategy making", International Public Management Journal, pp. 1-23. ISSN: 1096-7494print/ 1559-3169, online access in (30-10-2018), available at: www.Researchgate.net/publication/ 322693424

Khashaba, M. (1984), An Analytical Reflection on the Trends of Improving the Effectiveness of the Egyptian Administrative Entities by Applying the Field to Processes of Simplifying Procedures and Improving Existing Work Systems, National Planning Institute, Cairo.

Labib, G. (2019), the administrative reform plan between reality and the future, symposium at the National Planning Institute.

Mascio, F.D., et al. (2015), "The implementation of administrative burden reduction policy: mechanisms and contexts in the study of Europeanization", Comparative European Politics, on line access on 07-11-2018, available at: www.Comparative European Politics.

Minas, R. (2014), "One- stop shops: increasing employability and overcoming welfare state fragmentation”, International Journal of Social Welfare, Vol. 23 No. 56, pp. 40-53.

Ministry of Administrative Development Report, (2001), Distinguished Leadership Training Program, Central Organization for Administration and Management.

Ministry of Planning, Follow-up and Administrative Reform, (2014), Vision of Administrative Reform in Egypt, "Challenges of the Current Situation, available at: http://mpmar.gov.eg/ON line October 2019.

Morgan and Sturdy, (2000), Beyond Organizational Change, Macmillan Press, London.

Napicks, J. (2014), "Civil-oriented administrative simplification in German development", bachelor thesis on the subject of public administration, university of twenty, faculty of behavioral and social sciences.

OECD, (2003), From Red Tape to Smart Tape, Administrative Simplification in OECD Countries.

OECD, (2009), over barriers to administrative simplification strategies: guidance for policy makers, OECD e-library, available at: www.sourceoecd.org

OECD, (2011), progress in public management in the Middle East and North Africa: case studies on policy reform, OECD e-library, available at: www.sourceoecd.org

OECD, (2018), Compact for Economic Governance Stocktaking Report: Egypt, pp. 62-63, available at: www.oecd.org/mena/competitiveness/Compact-for-Governance-Stocktaking-ReporT

Pucek, M. and Spacek, D. (2014), "Strategic public management selected experiences", Transylvanian Review of Administration Sciences, No. 41, pp. 146-160.

Rabin, J., et al. (1990), "Handbook of strategic management", Public Administration and Public Policy, No. 38, pp. 36-56.

Schwnk, C.R. (1995), "Strategic, decision making”, Journal of Management, Vol. 2 No. 3, pp. $471-488$.

Smith, J. and McBain, L. (2010), Strategic Management in the E-Leader, Singapore, pp. 50-59.

Stewart, J. (2004), "The meaning of strategy in the public sector", Australian Journal of Public Administration, Vol. 63 No. 4, pp. 16-21.

The World bank (2011), Report.

Torres, L. and Piana, V. (2005), "Government and countries transformation in EU", New York Information Review, Vol. 29 No. 5, pp. 533-553.

Vancil, R. (1976), "Strategy formulation in complex organization”, Sloan Review, Vol. 17, p. 9.

West, D.M. (2009), Digital Government: Technology and Public Sector Performance, Princeton University P. 
Zakee, E. (2007), Marketing e-Government Services: A Working Paper Presented to a Seminar on Marketing e-Government Services in Arab Institutions, The Arab Organization for Administrative Development, Cairo, pp. 5-20.

\section{Further reading}

Brynard, D.J. (1995), “Combating red tape in the public sector”, International Journal of Public Sector Management, Vol. 8 No. 4, pp. 38-47.

Hampton final report, Review (2005), Reducing administrative burdens, effective inspection and enforcement, HM Treasury on behalf of the Controller of Her Majesty Stationery Office, UK.

Prime Minister Decision No. (20) Of (2019), “Concerning the supreme committee for One-Stop shop”.

Prime Minister Decision No. (4248), (2918), "For the year 1998 regarding the establishment of technological centers in cities and neighborhoods, and resolution no. (173) for the year 2011 amending them".

Prime Minister Decision No. 998 of (2019), "To reorganize the Central unit to review and simplify procedures (ERRADA)".

Presidential Decree No. 89 of (2017), "Regarding the establishment of the national council for government payments".

Scott, M., and and Gemmell, J.C. (2013), "Environmental regulation, sustainability and risk (22) sustainability, accounting", Management and Policy Journal, Vol. 4 No. 2, pp. 120-144.

E-government report from 2008-2018, available at: https://documents.worldbank.org/

Egypt Civil Service Law No. 81 of 2016.

EgyptVision2030, the axis of transparency and institutional efficiency.

CAOA Decision No. 87 of 2019 regarding the organizational division of information systems and digital transformation.

http://mpmar.gov.eg.

www.errada.gov.eg.

www.incometax.gov.eg/.

www.tamwin.com.eg/.

www.gfmis.mof.gov.eg.

www.egypt.gov.eg/Arabic/Home.aspx.

\section{Corresponding author}

Reem Mostafa Gobba can be contacted at:gobareem@gmail.com

For instructions on how to order reprints of this article, please visit our website: 